\title{
ANALISIS PENGARUH FAKTOR-FAKTOR PERILAKU TUGAS, PERILAKU HUBUNGAN, MOTIVASI INTRENSIK, MOTIVASI EKSTRENSIK, DAN LINGKUNGAN KERJA TERHADAP PRESTASI KERJA KARYAWAN BAGIAN PRODUKSI PT. MADUKARA MALANG
}

\author{
Sriwati \\ Fakultas Ekonomi Program Studi Manajemen \\ Universitas Riau Kepulauan
}

\begin{abstract}
Problem formulation which can be laid open in this research shall be as follows: 1) Whether behavioral factors of leader, motivate and environment work by together have an effect on to labour capacity of employees on part of production at PT. Madukara Malang, 2) Among behavioral factors of leader, motivate and environment work the, which factor having an effect on dominant to labour capacity of employees on part of production at PT. Madukara Malang. As for research target is to analyze the behavioral factors influence of leader, motivate, and environment work by together to labour capacity of employees on part of production at PT. Madukara Malang and also to analyze which the factors among behavioral factor of leader, motivate, and job environment having an effect on dominant to labour capacity of employees on part of production at PT. Madukara.

Result of test $\mathrm{F}$ indicate that by together behavioral variable of duty, behavioral of relation, motivate the intrinsic, motivate the extrinsic, and environment work by together have an effect on by significant to labour capacity of employees on part of production at PT. Madukara Worse luck, meaning progressively mount the duty behavioral, behavioral of relation, motivate the intrinsic, motivate the extrinsic, and environment work hence reached labour capacity will mount. Result of research indicate that the change of labour capacity equal to $78,2 \%$ because of change by together duty behavioral, behavioral of relation, motivate the intrinsic, motivate the extrinsic, and environment work, while the rest $21,8 \%$ because dissimilar variable which not checked.

Result of $t$ test obtained by result that duty behavioral, behavioral of relation, motivate the extrinsic and environment work to have an effect on by significant to labour capacity. In the reality behavioral variable of duty represent the dominant variable have an effect on to labour capacity, become the head behavioral represent the variable having an effect on dominant to labour capacity of employees on part of production PT. Madukara worse luck tested.
\end{abstract}

Keywords:

Leadership performance, Motivation, Work environment, Work performance

\section{PENDAHULUAN}

Tanggung jawab dari seorang pemimpin adalah mendorong karyawan ke arah pencapaian tujuan-tujuan yang bermanfaat. Karyawan perlu merasakan bahwa mereka memiliki sesuatu yang bermanfaat yang harus dilakukan dan sesuatu yang dapat dilakukan dengan sumber-sumber daya dan kepemimpinan yang tersedia. Hasil penelitian yang dilakukan oleh Ohio State University menurut Robbins (Pujaatmaka, 2007: 42) bahwa perilaku pemimpin dapat diidentifikasikan menjadi dua kelompok perilaku yang mempengaruhi efektifitas kepemimpinan, yaitu perilaku tugas/struktur inisiasi dan perilaku hubungan/konsiderasi. Perilaku tugas/struktur inisiasi cenderung lebih mementingkan tujuan organisasi dari pada memperhatikan bawahan. Sedangkan perilaku hubungan/konsiderasi cenderung kearah 
kepentingan bawahan. Dengan demikian apabila perilaku tugas dilaksanakan bersama-sama dengan perilaku hubungan yang dilakukan oleh pemimpin dengan derajat yang sama-sama tinggi maka cenderung dapat mencapai performance dan kepuasan karyawan yang relatif tinggi. Menurut Robbins (Pujaatmaka, 2007:71) pemimpin harus mampu mengantisipasi perubahan, memanfaatkan kesempatan, menciptakan lingkungan kerja yang nyaman untuk meningkatkan prestasi kerja karyawan, mengkoreksi kinerja yang buruk, memotivasi bawahan, dan mendorong organisasi ke arah pencapaian tujuan. Jadi pemimpin yang mampu mengkombinasikan secara tepat perilaku tugas dan perilaku hubungan, akan mampu memotivasi karyawan untuk bekerja lebih giat sehingga tercapai prestasi kerja yang tinggi.

Herzberg (Buchari, 2009:52) menyatakan ada dua faktor yang mempengaruhi motivasi kerja, yakni faktor intrensik dan faktor ekstrensik. Faktor intrensik, seperti : prestasi, pengakuan diri, kerja itu sendiri dan tanggung jawab, serta kemajuan dan pertumbuhan. Sedangkan faktor ekstrensik, seperti kebijakan dari pimpinan perusahaan, penyeliaan, hubungan antar pribadi dan kondisi kerja serta gaji yang sesuai.

Selain perilaku pemimpin dan motivasi kerja yang dapat meningkatkan prestasi kerja karyawan, faktor lingkungan kerja seperti tempat kerja dan perlakuan yang diterima karyawan juga mempengaruhi prestasi kerja karyawan. Hal ini disebabkan karena adanya lingkungan kerja yang menyenangkan membuat karyawan akan bekerja lebih bergairah dan bersemangat untuk mencapai prestasi kerja yang lebih baik.

PT. Madukara selalu berusaha semaksimal mungkin untuk memperbaiki prestasi kerja karyawan dalam rangka memenuhi permintaan konsumen, dengan melalui berbagai cara di antaranya mulai dari pembinaan dan pengarahan para Kepala Bagian Produksi, Pembungkusan, Gudang, Teknik dan lain-lain yang ada di perusahaan agar mampu memberikan tugas dan bimbingan kepada masing-masing bawahannya sehingga dapat bekerja secara maksimal. Kemudian meningkatkan motivasi kerja yang kondusif, baik motivasi intrensik maupun motivasi ekstrensik secara maksimal sehingga diharapkan karyawan akan berlombalomba untuk mengejar prestasi kerja terbaik. Selain kedua hal tersebut, pemimpin perusahaan juga memperhatikan dan meningkatkan lingkungan kerja yang kondusif, yakni menyediakan tempat kerja yang menyenangkan dan memberikan perhatian yang memuaskan karyawan, contoh menyediakan Musholla, ruang istirahat lengkap dengan TV dan sebagainya.

Dari gambaran tersebut di atas jelaslah bahwa perilaku pemimpin, baik perilaku tugas maupun perilaku hubungan, dan motivasi kerja serta penciptaan lingkungan kerja yang kondusif, dimungkinkan mempunyai pengaruh terhadap prestasi kerja karyawan, hal ini harus dikondisikan oleh perilaku pemimpin dalam rangka peningkatan prestasi kerja karyawan untuk mencapai tujuan perusahaan secara maksimal. Dari uraian tersebut perlu diteliti apakah faktor prestasi kerja karyawan bagian produksi di

PT. Madukara Malang dipengaruhi oleh faktor-faktor perilaku pemimpin, motivasi dan lingkungan kerja?.

\section{LANDASAN TEORI DAN HIPOTESIS}

a. Perilaku tugas adalah kadar perilaku pemimpin yang menggambarkan hubungan dirinya sendiri dengan anggota kelompok kerja untuk membentuk pola organisasi, saluran komunikasi dan metode atau prosedur yang ditetapkan dengan baik. Robbins (Pujaatmaka, 2007: 42)

b. Perilaku hubungan adalah kadar upaya pemimpin yang mengacu pada perilaku yang menunjukkan persahabatan, kepercayaan timbal balik, rasa hormat, dan kehangatan dalam hubungan antara pemimpin dengan anggota stafnya. (Robbins, 2007: 43)

c. Motivasi intrensik adalah motivasi yang berasal dari dalam diri seseorang (Nawawi, 2008:359). 
d. Motivasi ekstrensik adalah motivasi yang timbul dari luar diri seseorang (Nawawi, 2008:359).

e. Lingkungan kerja adalah lingkungan internal/psikologis perusahaan dan kebijakan sumber daya manusia yang diterima oleh karyawan-karyawan perusahaan. (Simamora, 2007:81).

f. Prestasi kerja adalah hasil kerja secara kualitas, kuantitas dan ketepatan waktu yang dicapai oleh seorang pegawai dalam melaksanakan tugasnya dengan tanggung jawab yang diberikan kepadanya. (Dharma, 2009: 35 ).

\section{Penelitian yang Relevan}

Penelitian yang dilakukan oleh Sitorus (2005), pada Kantor Daerah Telekomunikasi Bandung menyatakan bahwa terdapat hubungan positif antara motivasi kerja pegawai dengan peningkatan produktivitas kerja pegawai. Pengaruh motivasi terhadap produktivitas kerja mencapai $42 \%$,sedangkan sisanya $58 \%$ dipengaruhi oleh variabel - variabel lain.

Satriyo (2007), melakukan penelitian tentang pengaruh perilaku pemimpin, iklim organisasi, kinerja dan kepuasan kerja, dengan mengambil sampel sejumlah 66 staff pegawai pada Kantor Dinas Pendapatan Daerah Propinsi Jawa Timur Cabang Malang, menyatakan bahwa :

1. Perilaku pemimpin berpengaruh signifikan terhadap iklim organisasi.

2. Secara bersama-sama perilaku pemimpin dan tingkat iklim organisasi berpengaruh terhadap tingkat kinerja kelompok

3. Secara bersama-sama perilaku pemimpin, tingkat iklim organisasi, dan tingkat kinerja kelompok berpengaruh secara signifikan terhadap tingkat kepuasan kerja

Penelitian tentang pengaruh motivasi kerja terhadap peningkatan produktifitas kerja tenaga administrasi Universitas Pattimura oleh Pattikawa (2008), menyatakan bahwa terdapat hubungan yang sangat erat antara motivasi kerja dan efektivitas kerja.

Penelitian menurut Heru Cahyono (2010) dengan judul Faktor-faktor yang mempengaruhi prestasi kerja karyawan PDAM Kabupaten Tulungagung diperoleh bukti empiris dan signifikan bahwa variabel kemampuan dan ketrampilan merupakan variabel yang berpengaruh dan signifikan terhadap prestasi kerja karyawan.

Dari ringkasan di atas, maka persamaan penelitian yang dilakukan penulis dengan penelitian terdahulu adalah sama-sama meneliti tentang perilaku pemimpin, motivasi, lingkungan kerja dan prestasi kerja. Sedangkan perbedaannya, penulis mengadakan penelitian pada perusahaan swasta sedangkan peneliti terdahulu pada instansi pemerintah serta belum ada penelitian tentang pengaruh faktor-faktor perilaku pemimpin, motivasi dan lingkungan kerja terhadap prestasi kerja karyawan di perusahaan yang diteliti.

\section{Kerangka Konsep Penelitian}

Dalam penelitian ini, maka dapat digambarkan model hubungan kerja variabel penelitian sebagai berikut:

Gambar 1

Kerangka Konseptual Penelitian 


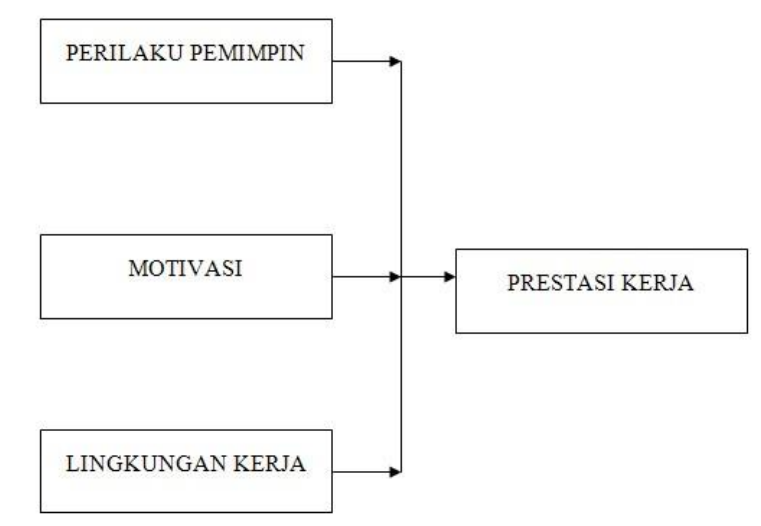

\section{HIPOTESIS}

Berdasarkan permasalahan dan landasan teori yang ada, maka dapat dikemukakan hipotesis, sebagai berikut :

1. Diduga faktor-faktor perilaku pemimpin, motivasi dan lingkungan kerja secara bersama - sama berpengaruh positif dan signifikan terhadap prestasi kerja karyawan bagian produksi PT. Madukara Malang.

2. Diduga bahwa perilaku pemimpin mempunyai pengaruh yang dominan terhadap prestasi kerja karyawan bagian produksi pada PT. Madukara Malang.

\section{METODE PENELITIAN}

Pendekatan penelitian menggunakan tipe penelitian penjelasan (Explanatory Research) dengan menggunakan metode survey yaitu penelitian yang berusaha menjelaskan pengaruh antara faktor perilaku pemimpin, motivasi dan lingkungan kerja terhadap prestasi karyawan. Data yang berhubungan dengan variabel penelitian dikumpulkan dari perusahaan dengan menggunakan wawancara terhadap responden dibantu dengan dokumentasi.

Dalam penelitian ini dikembangkan kegiatan penelitian yang mengarah pada disiplin ilmu Manajemen Sumber Daya Manusia untuk topik perilaku pemimpin, motivasi, lingkungan kerja dan prestasi kerja. Adapun bentuk penelitiannya adalah penelitian hubungan kausal antara variabel-variabel yang ada, yaitu pengaruh perilaku pemimpin, motivasi dan lingkungan kerja dengan prestasi kerja karyawan. Sedangkan ruang lingkup yang diteliti adalah karyawan bagian produksi perusahaan permen PT. Madukara Kota Malang.

\section{Variabel Penelitian}

\section{Perilaku Tugas $\left(\mathbf{X}_{1}\right)$}

Perilaku tugas adalah perilaku pemimpin untuk membentuk pola organisasi, saluran komunikasi, metode atau prosedur pelaksanaan tugas. Item yang digunakan meliputi:

1) Tujuan yang harus dicapai karyawan $\left(X_{1.1}\right)$

2) Prosedur kerja $\left(X_{1.2}\right)$

3) Pembagian tugas $\left(X_{1.3}\right)$

4) Jadual kerja $\left(X_{1.4}\right)$

5) Penyelesaian kerja $\left(X_{1.5}\right)$ 
6) Standar waktu $\left(\mathrm{X}_{1.6}\right)$

7) Kuantitas dan kualitas $\left(X_{1.7}\right)$

8) Penjelasan teknik kerja $\left(\mathrm{X}_{1.8}\right)$

9) Laporan hasil kerja $\left(\mathrm{X}_{1.9}\right)$

Pengukuran item tersebut atas dasar Skala Likert.

\section{Perilaku Hubungan $\left(\mathbf{X}_{2}\right)$}

Perilaku hubungan adalah perilaku pemimpin yang bersahabat, kepercayaan timbal balik, rasa hormat dan kehangatan. Item yang digunakan meliputi:

1) Dukungan terhadap pekerjaan $\left(X_{2.1}\right)$

2) Motivasi kerja $\left(X_{2.2}\right)$

3) Kesempatan berpendapat $\left(X_{2.3}\right)$

4) Mengikutsertakan karyawan $\left(X_{2.4}\right)$

5) Interaksi sesama karyawan $\left(X_{2.5}\right)$

6) Perhatian terhadap keluhan $\left(X_{2.6}\right)$

7) Koreksi hasil kerja $\left(\mathrm{X}_{2.7}\right)$

8) Perbaikan hasil kerja $\left(\mathrm{X}_{2.8}\right)$

Pengukuran item tersebut atas dasar Skala Likert.

a.

b. Motivasi Intrensik $\left(\mathbf{X}_{3}\right)$

Motivasi intrensik adalah motivasi yang timbul dari dalam diri individu karyawan. Item yang digunakan meliputi:

1) Tingkat Prestasi $\left(X_{3.1}\right)$

2) Tingkat Pengakuan diri $\left(\mathrm{X}_{3.2}\right)$

3) Kesesuaian kerja $\left(X_{3.3}\right)$

4) Ketrampilan kerja $\left(X_{3.4}\right)$

5) Tingkat Tanggung jawab $\left(X_{3.5}\right)$

6) Tingkat pemahaman $\left(X_{3.6}\right)$

Pengukuran item tersebut atas dasar Skala Likert.

c.

d. Motivasi Ekstrensik $\left(\mathbf{X}_{4}\right)$

Motivasi ekstrensik adalah motivasi yang timbul dari luar diri individu karyawan. Motivasi ini dapat berupa motivasi materi dan motivasi non materi. Motivasi yang bersifat materi adalah pemenuhan kebutuhan karyawan yang dapat dinilai secara ekonomis (berupa uang). Item yang digunakan meliputi:

1) Kesesuaian kebijakan $\left(X_{4.1}\right)$

2) Tanggap terhadap karyawan $\left(X_{4.2}\right)$

3) Hubungan dengan pimpinan dan antar karyawan $\left(X_{4.3}\right)$

4) Besarnya gaji dan upah $\left(\mathrm{X}_{4.4}\right)$

5) Sistem pembayaran gaji dan upah $\left(X_{4.5}\right)$

Pengukuran item tersebut atas dasar Skala Likert.

e.

\section{f. Lingkungan Kerja $\left(\mathbf{X}_{5}\right)$}

Lingkungan kerja yakni suatu keadaan dilingkungan internal perusahaan yang didalam melaksanakan pekerjaannya karyawan dan kebijakan pimpinan. Item yang digunakan meliputi:

1) Tempat kerja $\left(X_{5.1}\right)$

2) Fasilitas kerja $\left(\mathrm{X}_{5.2}\right)$

3) Keamanan kerja $\left(\mathrm{X}_{5.3}\right)$

4) Kesesuaian keputusan dengan keinginan karyawan $\left(X_{5.4}\right)$ 
5) Penghargaan $\left(X_{5.5}\right)$

Pengukuran item tersebut atas dasar Skala Likert.

g. Prestasi kerja karyawan ( Y)

Prestasi kerja karyawan adalah hasil produk atau jasa yang dicapai seseorang dalam pelaksanaan tugas sesuai dengan kriteria yang telah ditentukan yang merupakan bentuk akhir dari tanggung jawab karyawan. Indikator yang digunakan meliputi :

1) Kualitas hasil kerja $\left(\mathrm{Y}_{1}\right)$

a) Kesesuaian hasil dengan standar $\left(\mathrm{Y}_{1.1}\right)$

b) Kesesuaian kemampuan $\left(\mathrm{Y}_{1.2}\right)$

2) Kuantitas hasil kerja $\left(\mathrm{Y}_{2}\right)$

a) Kesesuaian hasil kerja dengan standar $\left(\mathrm{Y}_{2.1}\right)$

b) Tingkat kesalahan $\left(\mathrm{Y}_{2.2}\right)$

3) Ketepatan waktu kerja $\left(\mathrm{Y}_{3}\right)$

a) Standar waktu $\left(\mathrm{Y}_{3.1}\right)$

b) Kerja lembur $\left(\mathrm{Y}_{3.2}\right)$

Pengukuran item tersebut dengan menggunakan Skala Likert

Untuk lebih jelasnya tentang definisi operasional variabel lihat Skema Operasional Variabel pada gambar 3.

Gambar : 3

Skema Operasional Variabel

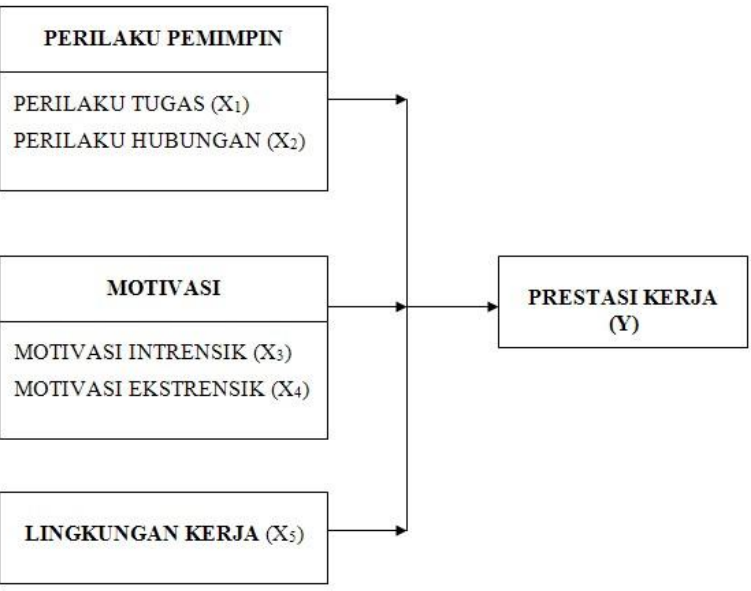

\section{Populasi dan Teknik Pengambilan Sampel}

Jumlah karyawan PT. Madukara Malang adalah 267 orang, adapun populasi dalam penelitian ini adalah seluruh karyawan bagian produksi yang berjumlah 75 orang, meliputi karyawan bulanan dan karyawan harian tetap. Penentuan populasi karyawan bagian produksi dengan pertimbangan agar penelitian lebih terfokus dalam menilai perilaku pimpinan, motivasi maupun lingkungan kerja dalam kaitannya dengan prestasi kerja, sebab bagian yang berbeda, tentunya perilaku pimpinan, motivasi maupun lingkungan kerja yang dibutuhkan juga berbeda.

Teknik pengambilan sampel dalam penelitian ini menggunakan metode Purposive Sampling dimana sampel diambil berdasarkan tujuan.. Menurut Mantra dan Kasto (Singarimbun, 1985 : 149) menyatakan bahwa 
besarnya sampel tidak boleh kurang dari 10\%. Agar pengambilan sampel reprentatif, maka sampel yang diambil dalam penelitian ini adalah sebesar 50\% dari jumlah anggota populasi, dengan pertimbangan karena populasi homogen, sehingga pengambilan sampel setengah dari anggota populasi sudah mewakili karakteristik populasi. Jadi besarnya sampel $=50 \%$ x $75=37$ karyawan.

\section{Teknik Analisis Data 1. Model Analisis}

Sebagaimana telah dikemukakan di depan bahwa penelitian ini ingin mengetahui dan menganalisis pengaruh faktor-faktor perilaku pemimpin, motivasi dan lingkungan kerja terhadap prestasi kerja karyawan bagian produksi, maka model yang digunakan dalam menganalisis data adalah berbentuk regresi liniear berganda dengan variabel bebasnya terdiri dari beberapa variabel dan kecenderungannya (trend) menunjukkan liniear atau tidak terjadi fluktuasi pada variabel bebas. Bentuk regresi liniear berganda dapat dirumuskan sebagai berikut :

$Y=a+b_{1} X_{1}+b_{2} X_{2}+b_{3} X_{3}+b_{4} X_{4}+b_{5} X_{5}+e$ Dimana

$\mathrm{Y}=\quad$ Prestasi kerja

$\mathrm{X}_{1}=$ Perilaku tugas

$\mathrm{X}_{2}=$ Perilaku hubungan

$\mathrm{X}_{3}=$ Motivasi intrensik

$\mathrm{X}_{4}=$ Motivasi ekstrensik

$\mathrm{X}_{5}=$ Lingkungan kerja

$\mathrm{a}=$ Konstanta

$b_{1}, b_{2}, b_{3}, b_{4}, b_{5}=$ koefisien regresi $\mathrm{e}$

$=\quad$ Variabel pengganggu

\section{Uji Asumsi Klasik}

Dalam penggunaan regresi, terdapat beberapa asumsi dasar yang dapat menghasilkan estimator linier tidak bias yang baik dari model regresi yang diperoleh dari metode kuadrat kecil biasa. Dengan terpenuhinya asumsi dasar ini maka hasil yang diperoleh dapat lebih akurat dan mendekati atau sama dengan kenyataan.

\section{Uji Hipotesis}

Untuk mengetahui diterima atau tidaknya hipotesis yang diajukan, yaitu dengan cara pengujian koefisien regresi secara serempak dengan uji F sesuai dengan metode analisis varians (anova) dan nilai $\mathrm{R}^{2}$, pengujian koefisien arah secara parsial dengan uji t. a. Pengujian Hipotesis I

Untuk menguji kebenaran hipotesis I digunakan uji $\mathrm{F}$ yaitu untuk menguji keberartian ( significance ) regresi secara keseluruhan, dengan rumusan hipotesis sebagai berikut :

Ho : $\square_{1}=\square_{2}=\square_{3}=\square_{4}=\square_{5}=0$

Ha : Minimal satu koefisien dari $\square i \neq 0$

Pengujian melalui uji $\mathrm{F}$ adalah dengan membandingkan $\mathrm{F}_{\text {hitung }}(\mathrm{Fh})$ dengan $\mathrm{F}_{\text {tabel }}(\mathrm{Ft})$ pada $\mathrm{C}$ $=0,05$. Rumus uji F:

\section{Rata $\square$ rata Kuadrat Regresi}

$\mathrm{F}$ hitung $=$ 


\section{Rata -rata Kuadrat Error}

Apabila hasil perhitungan menunjukkan:

1) $\mathrm{F}_{\mathrm{h}}>\mathrm{F}_{\mathrm{t}}(\mathrm{d} ; \mathrm{df}=\mathrm{k} ; \mathrm{n}-\mathrm{k}-1)$, maka : Ho ditolak; Ha diterima (significance)

Kaidah keputusan tolak Ho ( terima Ha ) berarti koefisien arah regresi secara serempak atau keseluruhan dapat digunakan sebagai model penduga (estimator) yang dipercaya untuk memprediksi pengaruh semua variabel bebas $(\mathrm{X})$ secara serempak terhadap variabel terikat $(\mathrm{Y})$.

2) $\mathrm{F}_{\mathrm{h}} \square \mathrm{F}_{\mathrm{t}}(\mathrm{d} ; \mathrm{df}=\mathrm{k} ; \mathrm{n}-\mathrm{k}-1)$, maka : Ho diterima (non significance) Ha ditolak

Artinya koefisien arah regresi secara serempak tidak dapat digunakan sebagai model penduga (estimator) yang dipercaya untuk memprediksi pengaruh semua variabel bebas $(\mathrm{X})$ secara keseluruhan terhadap variabel terikat (Y).

Selanjutnya untuk melihat kemampuan variabel bebas dalam menerangkan variabel terikat dapat diketahui dari besarnya koefisien determinasi linier (Adjusted $R$ Square). Dengan kata lain, nilai koefisien determinasi linier (Adjusted $R$ Square) digunakan untuk mengukur besarnya sumbangan dari variasi bebas yang diteliti terhadap variasi perubahan variabel terikat. Jika Adjusted $R$ Square yang diperoleh dari hasil perhitungan semakin besar (mendekati 1), maka dapat dikatakan bahwa sumbangan dari variabel bebas terhadap variasi variabel terikat semakin besar. Hal ini berarti model yang digunakan semakin tepat untuk menerangkan pengaruh variabel bebas terhadap variabel terikat. Sebaliknya, jika Adjusted R Square semakin kecil (mendekati nol), maka dapat dikatakan bahwa sumbangan dari variabel bebas terhadap variasi nilai variabel terikat semakin kecil. Hal ini berarti model yang digunakan semakin lemah untuk menerangkan pengaruh variabel bebas terhadap variabel terikat. Secara umum dapat dikatakan bahwa besarnya koefisien determinasi linier (Adjusted $R$ Square) berada antara 0 dan 1 atau $0<$ Adjusted R Square <1. b. Pengujian Hipotesis II

Untuk menguji kebenaran hipotesis 2 digunakan uji t, yaitu untuk menguji keberartian

(sifnificance) koefisien regresi parsial, dengan menggunakan rumus: $b i$

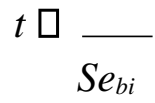

Dimana :

$\mathrm{Se}_{\mathrm{bi}}=$ Standar error dari koefisien regresi bi $=$

Koefisien regresi

Hipotesis statistiknya dinyatakan dengan :

Ho : $\square \mathrm{i}=0$

$\mathrm{Ha}: \mathrm{Di} \neq 0$

Pengujian dilakukan melalui uji $t$ dengan membandingkan $t$ hitung (observasi) $\left(t_{h}\right)$ dengan $t$ tabel $\left(\mathrm{t}_{\mathrm{t}}\right)$ pada $\mathrm{Q}=0,05$. Apabila hasil perhitungan menunjukkan :

1) $t_{h} \square t_{t}$ atau $t_{h} \square-t_{t}(1 / 2 \square ; d f=n-k-1)$ maka, Ho ditolak atau Ha diterima (significance), artinya (1) variasi bebas dapat menerangkan variabel terikat dan (2) ada pengaruh di antara dua variabel yang diuji.

2) $-\mathrm{t}_{\mathrm{t}} \square \mathrm{t}_{\mathrm{h}} \square \mathrm{t}_{\mathrm{t}}(1 / 2 \mathrm{2} \mathrm{df}=\mathrm{n}-\mathrm{k}-1)$ maka, Ho diterima atau Ha ditolak (non-significance), artinya (1) variasi bebas tidak dapat menerangkan variabel terikat, dan (2) ada pengaruh di antara dua variabel yang diuji. 


\section{HASIL PENELITIAN DAN PEMBAHASAN}

\section{Hasil Uji Validitas dan Reliabilitas}

Hasil uji validitas

Validitas menunjukkan tingkat kemampuan instrumen penelitian, mengukur apa yang hendak diukur dan dapat mengungkapkan data dari variabel yang diteliti secara tepat. Uji validitas menggunakan teknik korelasi Product Moment dengan cara mengkorelasikan skor masing-masing item dengan skor total. Instrumen dinyatakan valid jika nilai korelasi Product Moment ( $r$ hitung) lebih besar dari nilai $r$ tabel pada taraf nyata $\mathrm{C}=5 \%$.

Tabel Hasil Uji Validitas Instrumen

\begin{tabular}{|c|c|c|c|c|c|}
\hline Variabel & Item & $\begin{array}{c}\text { Nilai Korelasi } \\
(\mathrm{r} \text {, mang })\end{array}$ & $\begin{array}{c}\mathrm{f}_{\text {matel }} \\
(\alpha=5 \%)\end{array}$ & Pengujian & Keterangan \\
\hline $\mathrm{x} 1$ & 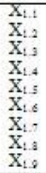 & $\begin{array}{l}0,08 \\
0,713 \\
0,632 \\
0,532 \\
0,456 \\
0,612 \\
0,612 \\
0,617 \\
0,728\end{array}$ & 0,325 & $r_{\text {bamag }}>r_{\text {atel }}$ & $\begin{array}{l}\text { Valid } \\
\text { Valid } \\
\text { Valid } \\
\text { Valid } \\
\text { Valid } \\
\text { Valid } \\
\text { Valid } \\
\text { Valid } \\
\text { Valid }\end{array}$ \\
\hline $\mathrm{x} 2$ & $\begin{array}{l}\mathrm{X}_{2.1} \\
\mathrm{X}_{2.2} \\
\mathrm{X}_{2,3} \\
\mathrm{X}_{2.4} \\
\mathrm{X}_{2,5} \\
\mathrm{X}_{2,6} \\
\mathrm{X}_{2,} \\
\mathrm{X}_{2,4}\end{array}$ & $\begin{array}{l}0,466 \\
0,648 \\
0,690 \\
0,461 \\
0,679 \\
0,726 \\
0,495 \\
0,508\end{array}$ & 0,325 & $\mathrm{I}_{\text {hitang }}>\mathrm{I}$ atel & $\begin{array}{l}\text { Valid } \\
\text { Valid } \\
\text { Valid } \\
\text { Valid } \\
\text { Valid } \\
\text { Valid } \\
\text { Valid } \\
\text { Valid }\end{array}$ \\
\hline $\mathrm{x} 3$ & 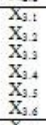 & $\begin{array}{l}0,671 \\
0,738 \\
0,671 \\
0,671 \\
0,494 \\
0,475\end{array}$ & 0,325 & I himang $>\mathrm{I}$ atel & $\begin{array}{l}\text { Valid } \\
\text { Valid } \\
\text { Valid } \\
\text { Valid } \\
\text { Valid } \\
\text { Valid }\end{array}$ \\
\hline $\mathrm{X} 4$ & $\begin{array}{l}\mathrm{X}_{4:} \\
\mathrm{X}_{4,2} \\
\mathrm{X}_{4,3} \\
\mathrm{X}_{4.4} \\
\mathrm{X}_{4,3}\end{array}$ & $\begin{array}{l}0,630 \\
0,855 \\
0,679 \\
0,792 \\
0,688\end{array}$ & 0,325 & $\mathrm{I}_{\text {hinasg }}>\mathrm{I}_{\text {thal }}$ & $\begin{array}{l}\text { Valid } \\
\text { Valid } \\
\text { Valid } \\
\text { Valid } \\
\text { Valid }\end{array}$ \\
\hline $\mathrm{X} 5$ & $\begin{array}{l}\mathrm{X}_{5: 1} \\
\mathrm{X}_{5,2} \\
\mathrm{X}_{5,3} \\
\mathrm{X}_{5,4} \\
\mathrm{X}_{5, s}\end{array}$ & $\begin{array}{l}0,561 \\
0,792 \\
0,758 \\
0,761 \\
0,790\end{array}$ & 0,325 & $I_{\text {hinumg }}>I_{\text {athel }}$ & $\begin{array}{l}\text { Valid } \\
\text { Valid } \\
\text { Valid } \\
\text { Valid } \\
\text { Valid }\end{array}$ \\
\hline $\mathrm{Y}$ & 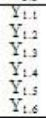 & $\begin{array}{l}0,812 \\
0,704 \\
0,499 \\
0,541 \\
0,840 \\
0,741\end{array}$ & 0,325 & $r_{\text {himang }}>\mathrm{r}_{\text {med }}$ & $\begin{array}{l}\text { Valid } \\
\text { Valid } \\
\text { Valid } \\
\text { Valid } \\
\text { Valid } \\
\text { Valid }\end{array}$ \\
\hline
\end{tabular}

Hasil uji validitas pada tabel dapat diketahui bahwa semua skor item berkorelasi signifikan dengan total skor, ditunjukkan nilai $r_{\text {hitung }}>r_{\text {tabel }}$. Korelasi yang signifikan antara skor item dengan total skor menunjukkan bahwa item yang digunakan dapat mengukur variabel yang diteliti, sehingga seluruh item pertanyaan dinyatakan valid.

\section{Hasil Uji Reliabilitas}

Reliabilitas menunjukkan sejauh mana hasil pengukuran tetap konsisten bila dilakukan pengukuran dua kali atau lebih terhadap gejala yang sama. Dalam penelitian ini, uji reliabilitas dilakukan dengan menggunakan metode Alpha Cronbach. Adapun hasil uji reliabilitas disajikan pada tabel berikut:

Reliabilitas instrumen menunjukkan sejauh mana alat pengukur dapat diandalkan atau menunjukkan sejauhmana konsistensi alat pengukur. Pengujian reliabilitas menggunakan metode Test-Retest dengan cara mengkorelasikan total skor kuesioner pertama dengan total skor kuesioner kedua dengan teknik korelasi Product Moment. Instrumen dinyatakan reliabel jika total skor tes I berkorelasi secara signifikan terhadap total skor tes II. Hasil korelasi Product Moment menunjukkan nilai korelasi = 0,943 (lampiran 
5) dan signifikan pada taraf nyata $\square=5 \%$ (nilai signifikan $<0,05$ ). Hal ini menunjukkan adanya hubungan yang kuat antara skor hasil pengukuran pertama dengan skor hasil pengukuran kedua. Hubungan yang kuat antara hasil skor tes I dengan hasil skor tes II menunjukkan adanya konsistensi, sehingga item pertanyaan dinyatakan reliabel.

\section{Deskripsi Variabel Penelitian}

Secara keseluruhan dari kesembilan item pertanyaan yang digunakan untuk mengukur perilaku tugas diperoleh rata-rata skor 3,51 berarti pimpinan bagian produksi di PT. Madukara sangat sering menerapkan perilaku tugas dalam tugasnya sehari-hari. Hal ini menunjukkan bahwa pimpinan sering menetapkan tujuan yang perlu dicapai oleh karyawan, mengorganisasi kerja, menetapkan batas waktu penyelesaian pekerjaan, memberikan arahan dan evaluasi berupa laporan hasil pekerjaan.

Kedelapan item pertanyaan yang digunakan untuk mengukur perilaku hubungan diperoleh rata-rata skor 3,64 berarti pimpinan di PT. Madukara sangat sering menerapkan perilaku hubungan dalam pelaksanaan tugas sehari-hari.

Secara keseluruhan dari keenam item pertanyaan yang digunakan untuk mengukur motivasi intrensik diperoleh rata-rata skor 3,31 berarti motivasi intrensik karyawan di PT. Madukara berada pada kategori baik. Hal ini menunjukkan bahwa karyawan memiliki dorongan yang besar untuk dapat menyelesaikan setiap tugas yang diberikan atau yang harus diselesaikan.

Kelima item pertanyaan yang digunakan untuk mengukur motivasi ekstrensik diperoleh rata-rata skor 3,34 berarti motivasi ekstrensik karyawan di PT. Madukara berada pada kategori baik.

Secara keseluruhan dari kelima item yang digunakan untuk mengukur variabel lingkungan kerja diperoleh rata-rata skor 3,19 berarti lingkungan kerja di PT. Madukara berada pada kategori baik.

Indikator ketepatan waktu kerja yang diukur dari dua item pertanyaan diperoleh rata-rata 3,06 berarti tingkat ketepatan waktu kerja karyawan di PT. Madukara Malang berada pada kategori baik. Secara keseluruhan dari ketiga indikator yang digunakan untuk mengukur prestasi kerja diperoleh rata-rata skor 2,96 berarti tingkat prestasi kerja karyawan di PT. Madukara berada pada kategori baik.

\section{Uji Asumsi Klasik}

\section{Asumsi Non Multikolinieritas}

Tabel Matrik Korelasi

Matrik Korelasi

\begin{tabular}{|c|c|c|c|c|c|}
\hline Korelasi & $\mathrm{X} 1$ & $\mathrm{X} 2$ & $\mathrm{X} 3$ & $\mathrm{X} 4$ & $\mathrm{X} 5$ \\
\hline $\mathrm{X} 1$ & 1 & & & & \\
\hline $\mathrm{X} 2$ & $-0,360$ & 1 & & & \\
\hline $\mathrm{X} 3$ & $-0,169$ & 0,287 & 1 & & \\
\hline $\mathrm{X} 4$ & 0,076 & $-0,220$ & $-0,316$ & 1 & \\
\hline $\mathrm{X} 5$ & 0,003 & $-0,265$ & $-0,296$ & $-0,351$ & 1 \\
\hline
\end{tabular}

Tabel menunjukkan antara variabel bebas yang satu tidak berkorelasi kuat dengan variabel bebas yang lain, ditunjukkan nilai koefisien korelasi antar variabel bebas mendekati 0 atau korelasinya lemah artinya 
variabel bebas tidak berkorelasi dengan variabel bebas yang lain sehingga bisa dikatakan tidak terjadi multikolinieritas.

\section{Asumsi Non Heteroskedastisitas}

\begin{tabular}{|c|c|c|c|c|c|c|c|c|}
\hline \multirow{2}{*}{\multicolumn{2}{|c|}{ Model }} & \multicolumn{2}{|c|}{$\begin{array}{l}\text { Unstandardized } \\
\text { Coefficients }\end{array}$} & \multirow{2}{*}{\begin{tabular}{|c|}
$\begin{array}{c}\text { Standardized } \\
\text { Coefficients }\end{array}$ \\
Beta \\
\end{tabular}} & \multirow{2}{*}{$\mathbf{t}$} & \multirow{2}{*}{ Sig. } & \multicolumn{2}{|c|}{ Co llinearity Statistics } \\
\hline & & B & Std. Error & & & & Tolerance & VIF \\
\hline \multirow{6}{*}{1} & (Constant) & -3.046 & .638 & & -4.775 & .000 & & \\
\hline & $\overline{X 1}$ & .433 & .111 & .355 & 3.891 & .000 & .842 & 1.187 \\
\hline & $\times 2$ & .399 & .148 & .268 & $\overline{2.691}$ & .011 & .707 & 1.414 \\
\hline & $x 3$ & .347 & .146 & .240 & 2.386 & .023 & .694 & 1.441 \\
\hline & $\mathrm{x} 4$ & .329 & .129 & .271 & 2.557 & .016 & .624 & 1.604 \\
\hline & $\times 5$ & .237 & .108 & .235 & $\overline{2.189}$ & .036 & .611 & 1.638 \\
\hline
\end{tabular}

Hasil uji heteroskedastisitas pada tabel menunjukkan bahwa semua variabel bebas berpengaruh signifikan terhadap residual sehingga dapat dikatakan dalam model regresi terjadi heteroskedastisitas.

\section{Asumsi Non Autokorelasi}

Hasil uji Durbin Watson diperoleh nilai $d=1,829$ sedangkan pada taraf $\square=5 \%$ diperoleh nilai $d u=1,80$ dan 4- $d u=2,2$ jadi nilai $d$ lebih besar dari $d u$ dan lebih kecil dari 4- $d u$ atau berada pada daerah tidak terjadi autokorelasi.

\section{Hasil Uji Hipotesis}

\section{Hasil Uji Hipotesis I}

Hasil analisis regresi berganda dapat disajikan pada tabel sebagai berikut:

Hasil Analisis Regresi Berganda

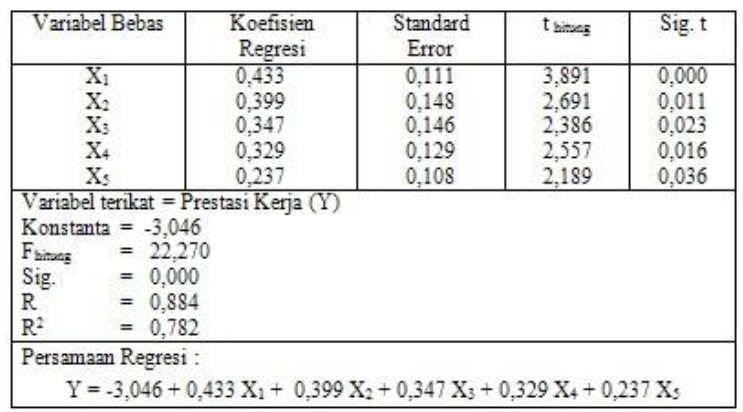


Pada tingkat kepercayaan 95\% $(\square=5 \%)$ diperoleh nilai $\mathrm{F}_{\text {tabel }}=2,53$ sedangkan nilai $\mathrm{F}_{\text {hitung }}=22,270$ sehingga $F_{\text {hitung }}>F_{\text {tabel }}$ dan nilai signifikan 0,000 lebih kecil dari 0,05 jadi teruji bahwa perilaku tugas, perilaku hubungan, motivasi intrensik, motivasi ekstrensik dan lingkungan kerja secara bersama-sama berpengaruh positif dan signifikan terhadap prestasi kerja karyawan bagian produksi di PT. Madukara Malang, dengan demikian hipotesis pertama teruji.

\section{Hasil Uji Hipotesis II}

Hasil uji regresi parsial menunjukkan bahwa kelima variabel bebas berpengaruh positif dan signifikan terhadap prestasi kerja, sehingga untuk mengetahui variabel yang berpengaruh dominan terhadap prestasi kerja dilihat dari besarnya koefisien regresi masing-masing variabel bebas, ternyata variabel perilaku tugas dengan koefisien regresi sebesar 0,433 merupakan koefisien regresi paling besar dan signifikan sehingga variabel perilaku tugas merupakan variabel yang berpengaruh paling dominan terhadap prestasi kerja, jadi hipotesis kedua teruji.

\section{Pembahasan}

Pengujian hipotesis pertama menunjukkan bahwa secara bersama-sama variabel perilaku tugas, perilaku hubungan, motivasi instrensik, motivasi ekstrensik, dan lingkungan kerja secara bersama-sama berpengaruh positif dan signifikan terhadap prestasi kerja teruji, yang ditunjukkan nilai $F_{\text {hitung }}(22,270)>F_{\text {tabel }}(2,53)$ dan nilai Sig. $0,000<0,05$. Berarti semakin baik perilaku tugas, perilaku hubungan, motivasi instrensik, motivasi ekstrensik, dan lingkungan kerja maka prestasi kerja yang dicapai akan meningkat. Hasil penelitian menunjukkan bahwa perubahan prestasi kerja sebesar 78,2\% disebabkan oleh perubahan secara bersama-sama perilaku tugas, perilaku hubungan, motivasi instrensik, motivasi ekstrensik, dan lingkungan kerja, sedangkan sisanya 21,8\% disebabkan oleh variabel lain yang tidak diteliti. Dengan demikian perilaku pemimpin yang diwujudkan dalam perilaku tugas dan perilaku hubungan, motivasi yang terdiri dari dari motivasi intrensik dan motivasi ekstrensik, serta lingkungan kerja secara bersamasama mempunyai pengaruh yang bermakna terhadap perubahan prestasi kerja karyawan bagian produksi. Kombinasi dari perilaku pemimpin yang baik, motivasi baik dari dalam diri karyawan maupun dari luar diri karyawan, serta kondisi tempat kerja yang baik akan menyebabkan peningkatan prestasi kerja karyawan bagian produksi. Hal ini cukup beralasan karena karyawan bagian produksi yang dijadikan sampel dalam penelitian ini merupakan karyawan operasional, dimana dalam menyelesaikan pekerjaan kayawan selalu membutuhkan petunjuk dan arahan dari pimpinan serta perhatian dari pimpinan terhadap pelaksanaan dan hasil kerja merka, karyawan selalu harus dimotivasi, akhirnya perlu ditunjang dengan tempat kerja yang memadai sehingga tercipta lingkungan kerja yang kondusif.

Hasil pengujian regresi parsial menunjukkan bahwa perilaku tugas berpengaruh positif dan signifikan terhadap prestasi kerja. Hal ini menunjukkan bahwa untuk mencapai prestasi kerja yang tinggi, pemimpin perlu menetapkan tujuan yang harus dicapai oleh karyawan, menetapkan prosedur kerja, melakukan pembagian tugas, jadual kerja, standar waktu penyelesaian tugas, kualitas dan kuantitas hasil kerja yang harus dicapai, dan laporan hasil kerja sebagai evaluasi akan menyebabkan karyawan bekerja sesuai dengan yang dikehendaki pimpinan, pelaksanaan tugas selalu terarah, pelaksanaan pekerjaan sesuai dengan prosedur, dan hasil pekerjaan akan dicapai sesuai dengan target yang ditetapkan sehingga akan tercapai prestasi kerja yang tinggi.

Perilaku hubungan teruji berpengaruh positif dan signifikan terhadap prestasi kerja, berarti semakin baik perilaku hubungan akan menyebabkan peningkatan prestasi kerja. Hal ini menunjukkan perlu adanya hubungan yang baik antara pimpinan dan bawahan, pimpinan harus selalu memberikan dukungan terhadap karyawan dalam menjalankan tugas, memberikan dorongan, memperhatikan keluhankeluhan karyawan, melakukan koreksi terhadap kesalahan dan memberikan petunjuk untuk memperbaiki kesalahan tersebut. 
Dengan demikian karyawan merasa diperhatikan, didorong dan diarahkan untuk penyelesaian pekerjaan, sehingga dicapai hasil kerja yang diinginkan perusahaan. Hasil penelitian ini sejalan dengan pendapat Day dan Lord yang dikutip Robbins (Pujaatmaka, 2007 : 71) yang menyatakan bahwa: sukses suatu organisasi, atau setiap kelompok dalam suatu organisasi sangat bergantung pada kualitas kepemimpinan. Pemimpin yang sukses mampu mengantisipasi perubahan, dan sekuat tenaga memanfaatkan kesempatan, memotivasi pengikut mereka, menciptakan lingkungan kerja yang nyaman untuk meningkatkan prestasi karyawan.

Motivasi instrensik teruji berpengaruh positif dan signifikan terhadap prestasi kerja, berarti semakin baik motivasi instrensik seorang karyawan akan menyebabkan peningkatan prestasi kerja. Hal ini menunjukkan bahwa seorang karyawan bersedia menyelesaikan pekerjaan jika memiliki dorongan dari dalam dirinya baik berupa keinginan berprestasi, berusaha memahami pekerjaan yang harus diselesaikan, dan tanggung jawab. Motivasi instrensik teruji berpengaruh positif dan signifikan terhadap prestasi kerja, berarti semakin baik motivasi ekstrensik seorang karyawan akan menyebabkan peningkatan prestasi kerja. Hal ini menunjukkan bahwa seorang karyawan akan mampu menyelesaikan pekerjaan jika atau dimotivasi dengan menciptakan lingkungan yang kondusif antara pimpinan dan karyawan, di antaranya pekerjaan yang harus diselesaikan disesuaikan dengan kemampuan karyawan, pimpinan selalu memperhatikan karyawan, serta gaji dan upah yang sesuai dengan pekerjaan yang harus diselesaikan. Hal ini sejalan dengan pendapat Winardi (2009:140-144), mengumukakan bahwa keseluruhan proses motivasi kepada para bawahan akan menyebabkan bawahan mau bekerja dengan ikhlas demi tercapainya tujuan organisasi secara efektif dan efisien. Apabila para bawahan mau bekerja dengan ikhlas niscaya apa yang menjadi tujuan perusahaan akan berhasil dan tentu saja di dalamnya terdapat faktor peningkatan prestasi kerja karyawan yang berdampak pada peningkatan prestasi organisasi.

Lingkungan kerja teruji berpengaruh positif dan signifikan terhadap prestasi kerja, berarti semakin baik lingkungankerja akan menyebabkan peningkatan prestasi kerja. Hal ini menunjukkan bahwa kondisi tempat kerja yang baik dan menyenangkan akan mendorong peningkatan prestasi kerja karyawan karena lingkungan kerja yang menyenangkan secara tidak langsung akan menekan stres kerja dan rasa kebosanan, demikian juga pengakuan pimpinan terhadap hasil kerja yang dicapai oleh karyawan harus selalu diperhatikan, penghargaan terhadap hasil kerja karyawan akan menimbulkan kepuasan bagi karyawan, karyawan merasa mampu memberikan hasil kerja yang diharapkan perusahaan, akhirnya termotivasi untuk terus meningkatkan hasil kerja yang dicapai. Sejalan dengan pendapat Simamora (2007 : 75) bahwa kondisi lingkungan kerja pada dasarnya dapat dibedakan menjadi lingkungan fisik atau tempat kerja dan kondisi psikososial yang meliputi perlakuan yang diterima, tempat kerja kerja yang memudahkan interaksi sosial yang tercipta tersebut dapat berpengaruh positif terhadap prestasi kerja karyawan.

Hasil penelitian menunjukkan bahwa perilaku tugas merupakan variabel yang dominan berpengaruh terhadap prestasi kerja, dengan demikian perilaku pemimpin merupakan variabel yang berpengaruh dominan terhadap prestasi kerja teruji. Dengan kata lain untuk mencapai peningkatan prestasi kerja maka harus diperhatikan perilaku pimpinan dalam perusahaan, apakah sudah berjalan dengan baik atau belum.

Hasil penelitian ini mengindikasikan bahwa untuk meningkatkan prestasi kerja karyawan bagian produksi, bukan hanya pada gaji dan upah yang layak tetapi lebih penting dari itu adalah perilaku tugas dan perilaku hubungan dari pimpinan. Artinya dalam menyelesaikan tugas karyawan, pimpinan harus menetapkan tujuan yang hendak dicapai dari pekerjaan yang dilakukan karyawan, dijelaskan prosedur kerja yang harus dijalankan, dilakukan pembagian tugas serta jadual kerja, diberikan batas waktu penyelesaian pekerjaan, ditetapkan kuantitas dan kualitas hasil kerja, ditetapkan standar waktu penyelesaian pekerjaan, dijelaskan teknik-teknik penyelesaian pekerjaan dan diminta laporan hasil kerja, sehingga pimpinan dapat mengevaluasi hasil kerja dari karyawan. Dengan demikian karyawan akan bekerja sesuai arah dan tujuan yang ingin dicapai perusahaan.

\section{KESIMPULAN}

1. Perilaku pempimpin, motivasi, lingkungan kerja teruji berpengaruh secara signifikan terhadap prestasi kerja karyawan bagian produksi PT. Madukara Malang. Dengan kata lain prestasi kerja karyawan bagian 
produksi dipengaruhi oleh perilaku tugas, perilaku hubungan, motivasi intrensik, motivasi ekstrensik, dan lingkungan kerja.

2. Perilaku tugas, perilaku hubungan, motivasi intrensik, motivasi ekstrensik, dan lingkungan kerja memberikan kontribusi sebesar 78,2\% terhadap perubahan prestasi kerja.

3. Variabel perilaku pemimpin merupakan variabel yang berpengaruh dominan terhadap prestasi kerja, yang ditunjukkan oleh koefisien regresi perilaku tugas memiliki nilai terbesar dan signifikan dibandingkan koefisien regresi motivasi dan lingkungan kerja.

4. Perilaku pemimpin lebih banyak ditentukan oleh perilaku tugas dibandingkan perilaku hubungan. Motivasi intrensik ternyata lebih besar dibandingkan motivasi ekstrensik dalam menentukan motivasi kerja karyawan bagian produksi. Prestasi kerja yang dicapai karyawan lebih banyak ditentukan oleh ketepatan waktu kerja yang berhasil dicapai oleh karyawan dibandingkan kuantitas dan kualitas hasil kerja.

5. Karyawan bagian produksi PT. Madukara Malang dengan latar belakang pendidikan sebagian besar SD dan SLTP dibutuhkan perilaku tugas yang lebih baik untuk dapat menyelesaikan pekerjaan sehingga dicapai prestasi kerja yang diharapkan, artinya pemimpin harus selalu memberikan instruksi kepada karyawan dalam menyelesaikan pekerjaannya.

\section{DAFTAR PUSTAKA}

Ancok, Djamaluddin, 1997, Teknik Penyusunan Skala Pengukur, Cetakan ke 9, Universitas Gajah Mada, Yogyakarta.

Azwar, Saifudin, 2008, Metode Penelitian, Edisi pertama, Cetakan ke lima, Pustaka Pelajar Offeset, Yogyakarta.

Buchari, Z. 2009, Manajemen dan Motivasi, Balai Aksara, Jakarta.

Cahyono, Heru, 2009, Faktor-faktor yang Mempengaruhi Prestasi Kerja Karyawan PDAM Kabupaten Tulungagung, Tesis, Program Pascasarjana, Universitas Brawijaya Malang.

Dharma, Agus 2011, Manajemen Prestasi Kerja, Rajawali Press, Jakarta.

Flippo, Edwin B, 2007, Manajemen Personalia, alih bahasa Moh. Mas’ud, Erlangga, Jakarta.

Gary, Yukl, 2004, Kepemimpinan dalam Organisasi, alih bahasa Yusuf Udaya, Prenhallindo, Jakarta.

Gibson, James, 1985, Organisasi dan Manajemen Perilaku Struktur Proses, alih bahasa oleh Djoerban Wachid, Penerbit Erlangga, Jakarta.

Hadi, Sutrisno, 2000, Analisis Butir, Ganesha, Bandung.

Handoko, TH, 2006, Manajemen Personalia dan Sumber Daya Manusia, Cetakan ke 10, BPFE, Yogyakarta.

Hasibuan, 2000, Manajemen Sumber Daya Manusia, Bumi Aksara, Jakarta.

Hersey, Paul and Kenneth. H. Blanchard, 2006, Manajemen Perilaku Organisasi : Sumber Daya Manusia, Penerjemah Agus Dharma, Erlangga, Jakarta.

Nasution, Ade Parlaungan, Ponco Bambang Mahargiono, and Yoyok Soesatyo. "Effect Of Leadership Styles, Organizational Climate And Ethos Of Work On Employee Productivity (Pt. Hp Metals Indonesia The Powder Coating)." DIMENSI 5.1 (2016). 
Nawawi, Hadari. 2008. Manajemen Sumber Daya Manusia. Cetakan Kedua. UGM University Press. Yogyakarta.

Nimran, Umar. 2009, Perilaku Organisasi, Edisi Revisi, Jakarta.

Pareek, Udai, 2006, Perilaku Organisasi Seri Manajemen No. 98, Cetakan ke 3, PT. Ikrar Mandiri Abadi, Jakarta.

Pattikawa, Benyamin, 2008, Pengaruh Motivasi Kerja terhadap Peningkatan Efektivitas Kerja Tenaga Administrasi Universitas Pattimura, Tesis, Program Pasca Sarjana Universitas Gajah Mada, Yogyakarta.

Ranupandojo, Heidjrahman, 2004, Manajemen Personalia, Penerbit BPFE, Yogyakarta.

Robbins, Stephen, 2007, Perilaku Organisasi, alih bahasa Hadyana Pujaatmaka, PT. Preshallindo, Jakarta.

Satriyo, 2007, Pengaruh Perilaku Pemimpin, Iklim Organisasi, Kinerja dan Kepuasan Kerja (Suatu Studi Pada Kantor Dinas Pendapatan Daerah Propinsi Tingkat I Jawa Timur Cabang Malang), Tesis, Program Pascasarjana Universitas Brawijaya, Malang.

Siagian, Sondang. P, 2010, Manajemen Sumber Daya Manusia, Cetakan ke 9, PT. Bumi Aksara, Jakarta.

Simamora, H. 2007, Manajemen Sumber Daya Manusia, Second Edition, STIE YKPN, Jakarta.

Singarimbun, Masri, 2009, Metode Penelitian Survai, Cetakan ke 2, LP3ES, Jakarta.

Sitorus, 2009, Pengaruh Motivasi Kerja Terhada Produktivitas Kerja Pegawai (Studi Pada Kantor Daerah Telekomunikasi Bandung), Tesis, Program Pascasarjana Universitas Gajah Mada, Yogyakarta.

Sugiyono, 2009, Statistika Untuk Penelitian, Alfabeta, Jakarta.

Swasto, Bambang, 2006, Pengembangan Sumber Daya Manusia, Pengaruhnya terhadap Kinerja dan Imbalan, FIA Universitas Brawijaya, Malang. 